\title{
Studies on Begonia (Begoniaceae) of the Moluccas III: A new Begonia from Seram, Indonesia
}

\author{
N.K.E. Undaharta ${ }^{1} \&$ W.H. Ardi ${ }^{2}$ \\ ${ }^{1}$ Bali Botanic Garden, Candikuning, Baturiti, Tabanan, \\ Bali, 82191, Indonesia \\ nika002@lipi.go.id \\ ${ }^{2}$ Bogor Botanic Garden, Jl. Ir. H. Juanda No. 13, \\ Bogor, Indonesia \\ wisn001@lipi.go.id
}

\begin{abstract}
A new species of Begonia, Begonia nephrophylla Undaharta \& Ardi, is described from Manusela National Park, Seram Island, Moluccas, Indonesia. The species is endemic to Seram and belongs to Begonia section Petermannia. An illustration of the new species and a key to the Moluccan species of Begonia is presented.
\end{abstract}

Keywords. Begonia, Indonesia, Moluccas, new species

\section{Introduction}

Begonia (Begoniaceae) is one of the largest genera of flowering plants and most species are found in the understorey in tropical forests (Tebbitt, 2005). The Moluccas have relatively few species compared to the other islands in the eastern part of Indonesia, Sulawesi and Papua. As for most of the region, the Begonia flora of the islands is poorly known, as indicated by recent new species discoveries (Wiriadinata, 2012; Ardi et al., 2014; Ardi \& Thomas, 2015; Ardhaka et al., 2016;) and as-yet undescribed species in both living and herbarium collections. Currently there are eight species known from the Moluccas, of which six are endemic to the archipelago or locally endemic to a single island (Table 1).

During the Begonia expedition to Seram which was carried out by "Eka Karya" Bali Botanical Gardens, Indonesian Institute of Sciences (LIPI) in 2010, several specimens suspected to be new to science were collected. Here a new species, named Begonia nephrophylla Undaharta \& Ardi, is described from material collected in Seram and cultivated at Bali and Bogor Botanic Gardens. The species belongs to Begonia section Petermannia (Klotzsch) A.DC. which is characterised by protogynous inflorescences, 2-flowered female inflorescences or solitary female flowers, 3-locular ovaries with axile placentation and bilamellate placentae, fruits with equal or subequal wings, and anthers with unilaterally positioned slits (Doorenbos et al., 1998). All available Begonia specimens from BO, E, K, L and SING (Thiers, continuously updated) have been consulted without any additional material being found and hence it must be assumed, at least until more intensive collecting reveals otherwise, that this species has a restricted range and is endemic to Seram. 
Table 1. Begonia species of the Moluccas (Wiriadinata, 2012; Ardi et al., 2014; Ardi \& Thomas, 2015; Hughes et al., 2015; Ardhaka et al., 2016).

\begin{tabular}{ll}
\hline Species & Locality \\
\hline Begonia aptera Blume & Mollucas, Papua, Sulawesi \\
Begonia aketajawensis Ardi \& D.C.Thomas & Halmahera \\
Begonia galeolepis Ardi \& D.C.Thomas & Seram \\
Begonia holosericea (Teijsm. \& Binn.) Teijsm. \& Binn. & Ternate \\
Begonia holosericeoides Ardi \& D.C.Thomas & Halmahera \\
Begonia manuselaensis Ardhaka \& Ardi & Seram \\
Begonia rieckei Warb. complex species & Mollucas, Papua, Sulawesi \\
Begonia sageaensis Wiriad. & Phillipines, Pacific Islands \\
\hline
\end{tabular}

Begonia nephrophylla Undaharta \& Ardi, sp. nov. (Section Petermannia) Species resembling Begonia galeolepis Ardi \& D.C.Thomas in the creeping habit and the sparse to moderately dense indumentum of fleshy, branched, appressed red scales on stems, petioles and abaxial leaf lamina veins, but differs consistently by shorter petioles (3-8 cm vs 7-22 $\mathrm{cm}$ in B. galeolepis), smaller kidney-shaped leaves (5-7 $\times 8-11 \mathrm{~cm}$ vs $12.5-17.2 \times 16-23.8 \mathrm{~cm})$, generally shorter male flower pedicels $(4-5$ $\mathrm{cm}$ vs $4-11 \mathrm{~cm}$ ), obovate male flower tepals (vs broadly ovate), and fewer stamens (35-40 vs 45-51). - TYPE: Originally a living collection from Indonesia, Moluccas, Sawai Village, Manusela National Park, grown on as cultivated material, vouchered and selected as type material on 18 April 2016 as N.K.E. Undaharta 4 (holotype BO; isotypes THBB (Herbarium Hortus Botanicus Baliense, Bali Botanic Gardens), KRB, SING. (Fig. 1, 2)

Perennial, monoecious herb, stem creeping, not rhizomatous, rooting where nodes touch the substrate, up to c. $30 \mathrm{~cm}$ long; stems, petioles, primary and secondary veins on the abaxial leaf lamina surfaces with a sparse to moderately dense indumentum of multicellular, red scales up to $4 \times 2 \mathrm{~mm}$. Stem branched, internodes 3-4 cm, green or reddish with short white stripes or spots. Leaves alternate; stipules persistent, $12-15 \times 5-8 \mathrm{~mm}$, ovate to narrowly triangular, acuminate, setose, margin entire and sometimes slightly revolute, reddish, translucent at the margins; petioles $\mathrm{c} .3-8 \mathrm{~cm}$ long, adaxially deeply channelled, moderately covered by red scales which form a ring at the attachment of the petiole to the lamina base; lamina basifixed, 5-7 $\times 8-11 \mathrm{~cm}$, broadly ovate to suborbicular, base cordate and lobes not overlapping, apex rounded or slightly acute, margin denticulate, the teeth bristle-pointed, adaxially dark green, glabrous, prominent between the veins, abaxial surface green and sparsely hairy on the veins, primary veins $7-10$, actinodromus, secondary veins brochidodromus. 


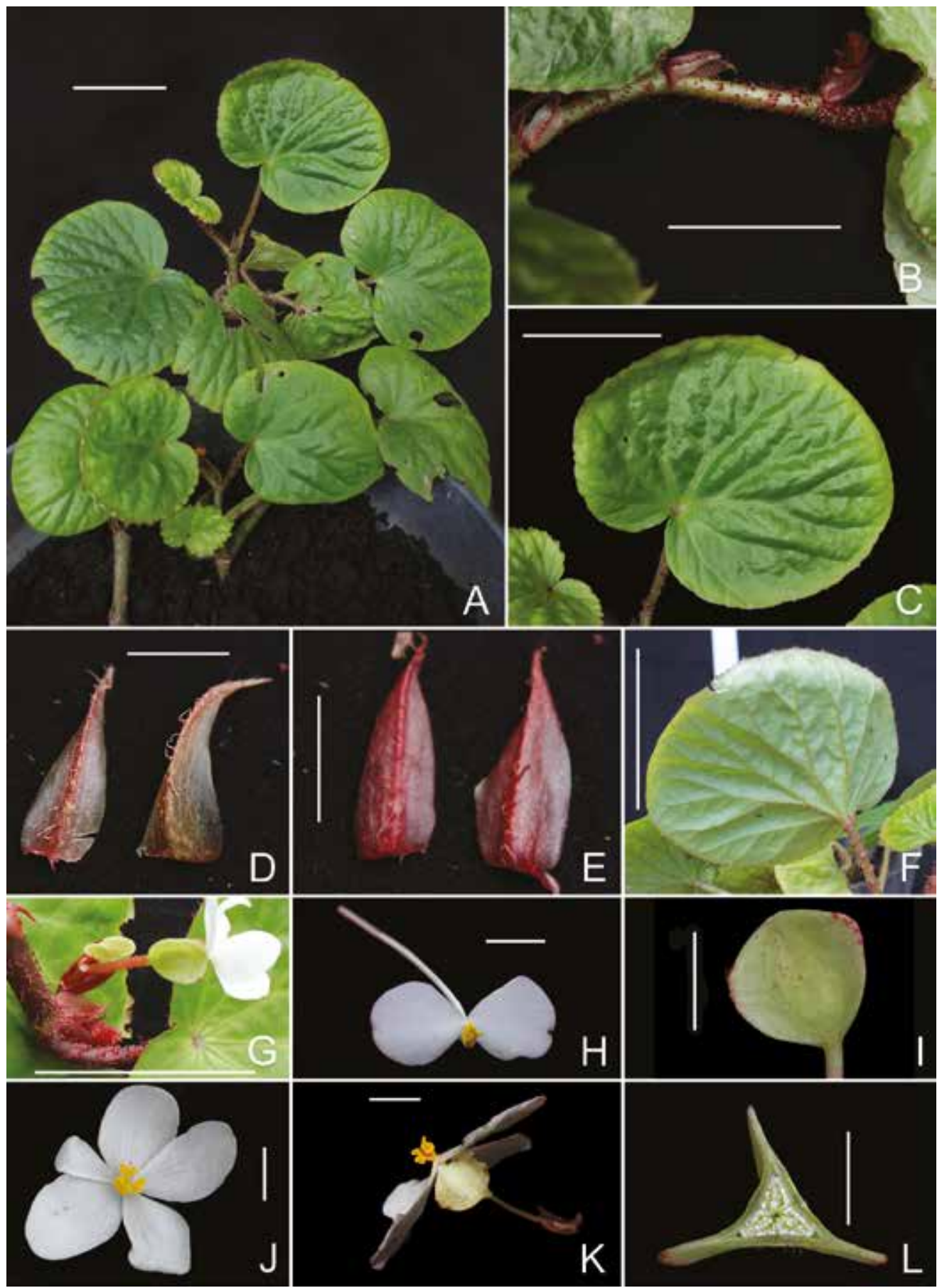

Fig. 1. Begonia nephrophylla Undaharta \& Ardi A. Growth habit in cultivation. B. Red scales on stem and stipules. C. Adaxial leaf surface. D. Stipules. E. Bracts. F. Abaxial leaf surface. G. Inflorescence. H. Male flower. I. Fruits. J-K. Female flower. L. Ovary transverse section. Scale bars: A-C, F, G $=5 \mathrm{~cm}$; D, E, H-L $=1 \mathrm{~cm}$. (Photos: Gede Wawan Setiadi) 


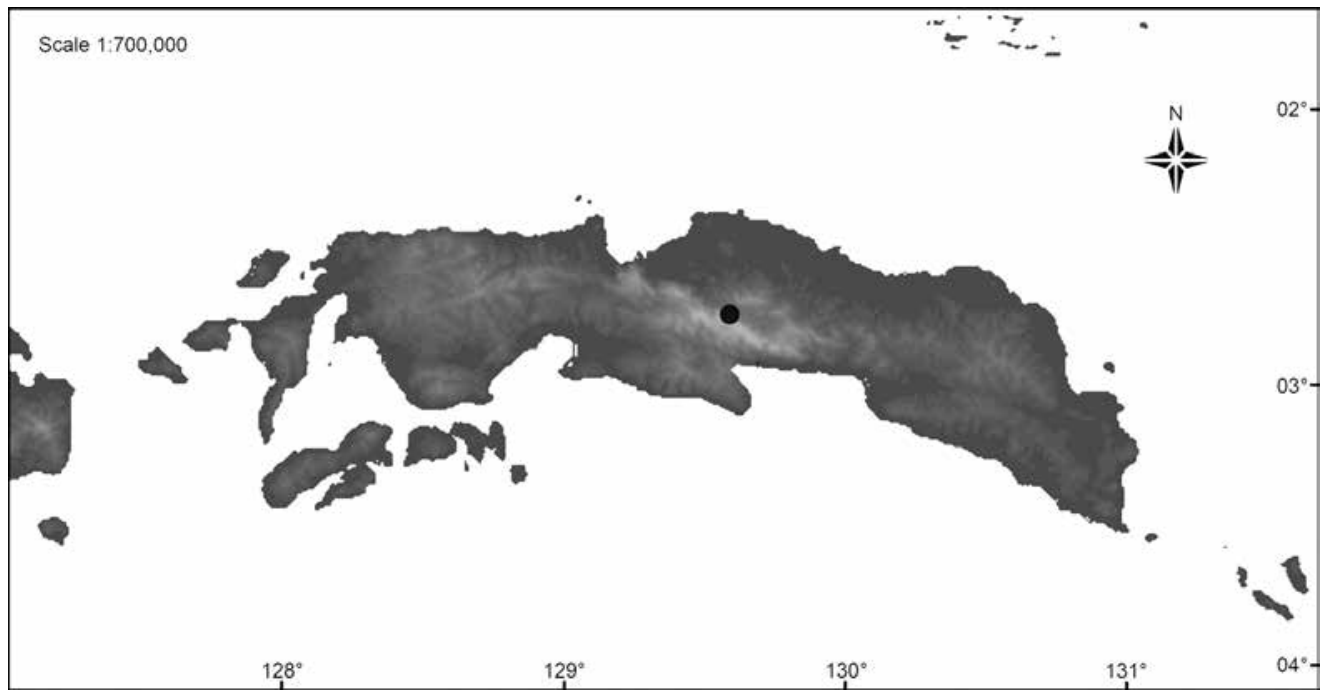

Fig. 2. Distribution of Begonia nephrophylla Undaharta \& Ardi. Collection sites are indicated by a circle (Manusela National Park). Specimen location information was georeferenced using the GeoNames geographical database (http://www.geonames.org/).

Inflorescences axillary, protogynous, female partial inflorescence 1-2-flowered, basal to the male partial inflorescences, peduncles c. $3 \mathrm{~mm}$ long; male partial inflorescences 2-3, monochasial, each monochasium with 2-4 flowers, peduncles c. $5 \mathrm{~mm}$ long; bracts ovate to elliptic, $10-20 \times 7-10 \mathrm{~mm}$, creamy, tinged pink, with an abaxially prominent midrib and sparse tiny red scales, apex projecting acuminate. Male flowers: pedicels 4-5 cm long, glabrous; tepals two, white or white with a pink tinge at the margin, abaxially glabrous, obovate, 14-16 × 14-15 mm; androecium of 35-40 stamens, yellow, filaments 1-2 mm long, slightly fused at the very base, anthers c. 1-1.5 mm long, obovate, dehiscing through unilaterally positioned slits c. 1/2 as long as the anthers. Female flowers: pedicel 1.8-2 cm long, sparsely hairy, red to green; tepals (4-)5, white tinged with pink, unequal, the four larger 20-21 × 12-18 mm, obovate, the smallest 16-17 × 3-4 mm, elliptic, abaxially glabrous; ovary obovoid, 10$12 \times 5-6 \mathrm{~mm}$ (excluding the wings), green, glabrous but sometimes sparsely red hairy, locules 3 , placentation axile, placentae bilamellate, wings 3 , green to reddish, base rounded, apex cuneate, style basally fused, 3-branched, each stylodium bifurcate in the stigmatic region, stigmatic surface a spirally twisted papillose band, orange. Fruits borne on pedicels up to $4 \mathrm{~cm}$ long, capsule obovoid, up to c. $19 \times 10 \mathrm{~mm}$ (excluding the wings), sparsely hairy, dehiscent, wing shape as for ovary. Seeds unknown.

Distribution. Endemic to Seram, Manusela National Park, locally common.

Habitat. Primary lowland rainforest, growing on damp soil, near a river in light shade, 19 m altitude. 
Etymology. The specific epithet is derived from the Greek nephros (kidney) and phyllum (leaf). Refers to the leaf shape which resembles a kidney.

Notes. The character of a creeping stem in Begonia section Petermannia is not well represented in Asia except in a number of species in Borneo (B. bosuangiana S.Julia, B. bakunensis S.Julia, B. benaratensis S.Julia, B. conipila Irmsch. ex Kiew, B. crockerensis Rimi, B. divergens Kiew \& S.Julia, B. johariana S.Julia \& C.Y.Ling, B. kachak K.G.Pearce, B. kasutensis K.G.Pearce, B. kiamfeii Kiew \& S.Julia, B. kinahimiae Rimi, B. lucychongiana S.Julia \& Kiew) (Kiew et al., 2015; Repin et al., 2015), the Moluccas (B. aketajawensis, B. holosericea, B. holosericeoides, $B$. manuselaensis, B. galeolepis, B. sageaensis) (Wiriadinata, 2012; Ardi et al., 2014; Ardi \& Thomas, 2015; Hughes et al., 2015; Ardhaka et al., 2016) and Sulawesi (B. gemella Warb. ex L.B.Sm. \& Wassh., B. heteroclinis Miq. ex Koord. and B. flacca Irmsch.) (Thomas et al., 2013), but Begonia nephrophylla can easily be distinguished from all of these species by the moderately dense indumentum of fleshy, branched, appressed red scales on the stems, petioles and abaxial leaf lamina veins. Otherwise Begonia nephrophylla is morphologically similar to B. galeolepis from Seram except that its creeping stem never tends to be erect or semi erect, while in B. galeolepis it initially has a semi-erect stem which becomes creeping when older. Other characters to distinguish the two species are given in the diagnosis.

Provisional IUCN conservation assessment. Data Deficient (DD). Begonia nephrophylla is known from a single locality in a legally protected area, Manusela National Parks, where no signs of major anthropogenic disturbance were noticed. Further exploration is required to assess the species' current range.

Identification key to Begonia in the Moluccas

(updated from Ardi et al., 2014)

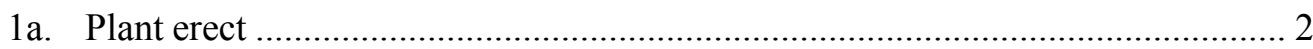

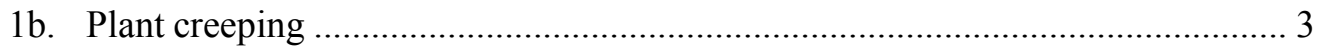

2a. Leaves broadly ovate; female flowers with 2-5 tepals; male flowers with 2 tepals, anther connectives not projecting at apex ............................. B. rieckei complex

2b. Leaves oblong, elliptic or broadly elliptic; female flowers with 6 tepals; male flowers with 4 tepals, anther connectives projecting at apex B. aptera

3a. Stem with branched hairs ........................................................................ 4

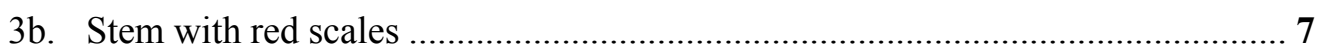

4a. Male flower with 4 tepals; leaves obovate to orbicular B. aketajawensis

4b. Male flower with 2 tepals; leaves ovate or broadly ovate to suborbicular 5 
5a. Leaves densely hairy on both sides B. sageaensis

5b. Leaves upper surface glabrous 6

6a. Leaves broadly ovate to suborbicular with rounded apex; female inflorescence peduncle 2-3 mm long; ovaries densely hairy B. holosericea

6b. Leaves ovate with acuminate apex; female inflorescence peduncle $1.1-3.5 \mathrm{~cm}$ long; ovaries sparsely hairy or glabrous B. holosericeoides

7a. Stem thin with sparse, small, red, flattened scales on the stem and petioles; leaves small $(4.8-7 \times 3-5 \mathrm{~cm})$, ovate to elliptic; male partial inflorescences $1(-2)$ per inflorescence B. manuselaensis

7b. Stem thicker with moderately dense larger red flattened scale and petioles, larger broadly ovate or suborbicular leaves $(>7 \times 5 \mathrm{~cm})$; male partial inflorescences 2-3 per inflorescence

8a. Leaves adaxially green to reddish, broadly ovate or suborbicular, 16-23.8 $\times 12.5-$ $17.2 \mathrm{~cm}$, apex acuminate; male flower pedicels $4-11 \mathrm{~cm}$ long, tepals broadly ovate, stamens 45-51; female flower tepals 5(-6), abaxially sparsely hairy to glabrescent, ovary wings with slightly rounded to cuneate base, apex of wings truncate B. galeolepis

8b. Leaves adaxially dark green, suborbicular, 8-11 $\times 5-7 \mathrm{~cm}$, apex shortly acute or rounded; male flower pedicels 4-5 cm long, tepals obovate, stamens 35-40; female flower tepals (4-)5, abaxially glabrous, ovary wings with rounded base, apex of wings cuneate B. nephrophylla

ACKNOWLEDGEMENTS. We thank the Begonia expedition to Seram team members, I Gede Tirta, I Made Ardhaka and I Putu Suparta, the curators of A, B, BM, BO, CEB, E, K, L and SING for allowing us access to herbarium material, and Daniel Thomas and David Middleton for their comments and correcting the English.

\section{References}

Ardhaka, I.M., Ardi, W.H., Undaharta, N.K.E. \& Tirta, I.G. (2016). A new species of Begonia from Manusela National Park, Seram. Reinwardtia 15(1): 61-64.

Ardi, W.H. \& Thomas, D.C. (2015). Studies on Begonia (Begoniaceae) of the Moluccas II: A new species from Seram, Indonesia. Gard. Bull. Singapore 67(2): 297-303.

Ardi, W.H., Kusuma, Y.W.C., Lewis, C.E., Risna, R.R., Wiriadinata, H., Abdo, M.E. \& Thomas, D.C. (2014). Studies on Begonia (Begoniaceae) of the Molucca Islands I: Two new species from Halmahera, Indonesia, and updated description of Begonia holosericea. Reinwardtia 14: 19-26.

Doorenbos, J., Sosef, M.S.M. \& De Wilde, J.J.F.E. (1998). The sections of Begonia including descriptions, keys and species lists (Studies in Begoniaceae VI). Wageningen Agric. Univ. Pap. 98(2): 1-266. 
Hughes, M., Moonlight, P., Jara, A. \& Pullan, M. (2015). Begonia Resource Centre. Royal Botanic Garden Edinburgh. http://elmer.rbge.org.uk/begonia/ (accessed on 11 Jun. 2016).

Kiew, R., Sang, J., Repin, R. \& Joffre, A.A. (2015). A Guide to Begonias of Borneo. 294 p. Kota Kinabalu: Natural History Publications (Borneo).

Repin, R., Sang, J., Kiew, R. \& Mujih, H. (2015). Eleven new species of Begonia (Begoniaceae) from the Crocker Range, Sabah, Malaysia. Phytotaxa 208(1): 1-20.

Tebbitt, M.C. (2005). Begonias: Cultivation, Identification and Natural History. Portland: Timber Press, Inc.

Thiers, B. (continuously updated). Index Herbariorum: A global directory of public herbaria and associated staff. New York Botanical Garden's Virtual Herbarium. http://sweetgum. nybg.org/science/ih/ (accessed on 8 Mar. 2016).

Thomas, D.C., Ardi, W.H., Girmansyah, D. \& Hughes, M. (2013). Sulawesi Begonia Data Portal. http://portal.cybertaxonomy.org/flora-malesiana-prospective/ (accessed on 24 Aug. 2016).

Wiriadinata, H. (2012). A new species of Begonia (Begoniaceae) from Sagea Lagoon, Weda Bay, Halmahera Island, North Moluccas, Indonesia. Reinwardtia 13(3): 263-270. 
